\title{
Calibration of RC Columns Using Fiber Elements
}

\author{
${ }^{1 *}$ Fazil Abdulkadir Caglar and ${ }^{2}$ Tuba Tatar \\ ${ }^{1 *}, 2$ Faculty of Engineering, Department of Civil Engineering Sakarya University, Turkey
}

\begin{abstract}
Although experimental studies have proven as the most effective method, its high cost has provoked researchers to seek alternative approaches. The increase in computational power in the $21^{\text {st }}$ century provides the opportunity to numerically model experimental studies with various programs. This study examines the comparison of force-based element and displacement-based element in columns using nonlinear fiber elements. Within the scope of the study, OpenSees program is employed for columns selected from the PEER (Structural Performance Database) site. The aim is to compare the employment of the FB element and DB elements in RC columns in terms of number of elements and integration points, to simulate the global behavior of the columns numerically, and to optimize the parameters that affect the results.
\end{abstract}

Key words: Fiber Elements, Reinforced Concrete, Calibration, Finite Elements, OpenSees

\section{Özet}

Deneysel çalışmaların en etkili yöntem olduğu kanıtlanmış olmasına rağmen, maliyetinin yüksek olması araştırmacıları alternatif yöntemler aramaya yöneltmiştir. 21. yüzyılda hesaplama gücünün artması, deneysel çalışmaların çeşitli programlarla sayısal olarak modellenmesine olanak sağlamaktadır. Bu çalışma, doğrusal olmayan fiber elemanların kullanıldığı kolonlarda kuvvet tabanlı eleman ile yer değiştirme tabanlı elemanın karşılaştırmasını incelemektedir. Çalışma kapsamında PEER (Yapısal Performans Veritabanı) sitesinden seçilen kolonlar için OpenSees programı kullanılmıştır. Amaç, RC sütunlarında FB elemanı ve DB elemanlarının istihdamını eleman sayısı ve entegrasyon noktaları açısından karşılaştırmak, kolonların global davranışını sayısal olarak simüle etmek ve sonuçları etkileyen parametreleri optimize etmektir.

Anahtar Kelimeler: Fiber Elemanlar, Güçlendirilmiş Beton, Kalibrasyon, Sonlu Elemanlar, OpenSees

\section{Introduction}

${ }^{*}$ Corresponding author: Fazil Abdulkadir Caglar Address: Faculty of Engineering, Department of Civil Engineering Sakarya University, 54187, Sakarya TURKEY. E-mail address: fazilabdulkadir.caglar@ibu.edu.tr 
Experimental studies are one of the most effective methods in examining the behavior of building and building elements. It is possible to have information about the structure or the behavior of the structural element without doing experimental work after the computational power increases. It is necessary to verify that the models made in these programs can give results close to the experimental studies at a sufficient level. If the results obtained are suitable, the behavior of the building elements can be obtained in a short time with different variables. In this way, compared to experimental studies, results can be obtained in a much shorter time, and more results can be obtained by trying different parameters.

Distributed inelasticity elements are employed in earthquake engineering applications such as research or professional engineering purposes. Concentrated plasticity and distributed plasticity are the two general approaches used in the numerical analysis of frame structures. The concentrated plasticity assumes that the nonlinear behavior is in a limited zone, mainly in a zero-length element, and the remaining part of the element behaves linearly. Although concentrated plasticity is an approach that has been used and accepted for many years, the distributed plasticity approach has developed considerably with the advancement of computer power. With distributed inelasticity models, the inelasticity is dispersed at each section throughout the member. The inelasticity of the frame is controlled by each integration point. This approach shows a profound closeness to the experimental results [1]. The distributed plasticity is also explored in two main finite element formulations: force-based and displacement-based formulations within the fiber element concept (in addition, OpenSees offer an element mixing force-based element and concentrated plasticity as a third option, named "beamwithhinge element"). The fiber element in the distributed plasticity is a method based on uniaxial stress-strain curves of the material, discretizing the sections into many fiber elements at the sectional level and IPs along the element length. The approach is very popular in earthquake engineering and the open-source software, OpenSees, provides a very wide, accessible, and independent platform for the users. Figure 1 illustrates the comparison of the plasticity types.
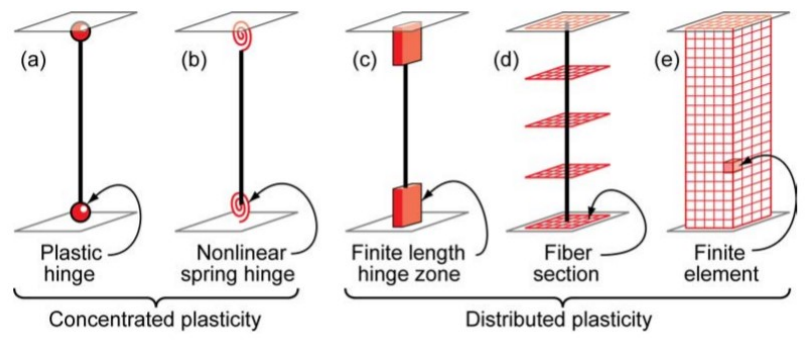

Figure 1. Various of the type of plasticity in an element [1]

This study examines the comparison of force-based elements and displacement-based elements in columns using nonlinear fiber elements. Within the scope of the study, the OpenSees program is employed for columns selected from the PEER (Structural Performance Database) site. The aim is to compare the employment of the FB element and DB elements in RC columns in terms of the number of elements and integration points, to simulate the global behavior of the columns numerically, and to optimize the parameters that affect the results. 


\section{Selection of Columns and Their Properties}

The PEER Database is utilized while selecting the experimental test in this study [2]. During the selection process, the failure type of the column is the key parameter and the columns with flexural failure are selected. Table 1 shows the column selection window of the PEER Database summarizes the material and geometrical properties of the selected columns for the paper.

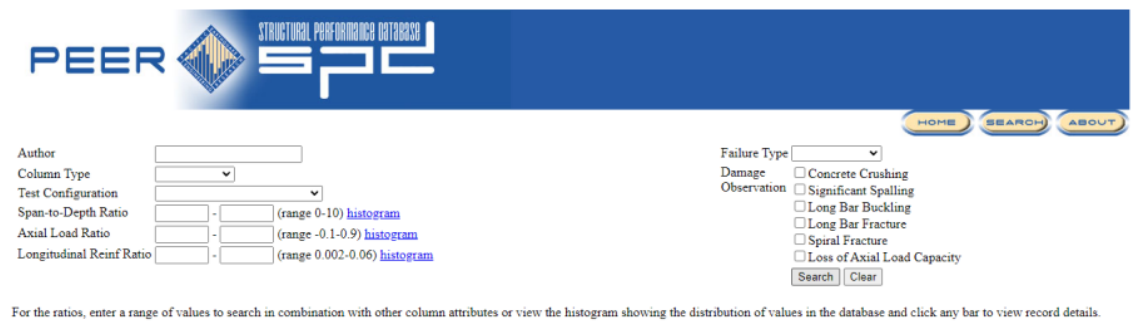

Figure 2: The selection window of the PEER Database [3]

\section{a.Selected Columns}

\section{Bayrak_AS-6HT Column}

(Bayrak,1996), presents the results of an ongoing research program aimed at examining concrete wrapping with lateral reinforcement. The present study is concerned with the experimental behavior of high strength concrete (HSC) and ultra-high strength concrete (UHSC) column behavior. In experimental program, specimen consisted of a $305 \times 305 \times 1473 \mathrm{~mm}$ column and they applied $4360 \mathrm{kN}$ axial load.[4]

\section{Matamoros_C10-05S Column}

(Matamoros,1999), was carried out to investigate the behavior of columns made with high-strength concrete subjected to shear reversals. The main variables of the experimental study were axial load and concrete strength. Column dimensions and the amount of transverse reinforcement did not vary between specimens. The dimensions of the samples are $203 \times 203 \times 610 \mathrm{~mm}$. The axial load we used in our study is $142 \mathrm{kN}$. [5]

\section{Ohno L2 Column}

(Ohno,1984), have proposed that the energy absorption capacity of structures is well-suited index for seismic safety. They investigate the energy absorption capacity of structures quantitatively. Five reinforced concrete columns were tested under four types of repeated loading. The dimensions of the samples are 400x 400x1600 mm. The axial load we used in our study is $127 \mathrm{kN}$. [6]

\section{Saatcioglu_BG8 Column}

(Saatcioglu,1999) Experimental research was conducted to investigate structural performance of reinforced concrete columns confined with welded grids. Ten column specimens were designed, constructed and tested. The dimensions of the samples are 350x 350x1645 mm. The axial load we used in our study is $961 \mathrm{kN}$. [7]

\section{Saatcioglu_U7 Column}

(Saatcioglu,1989) In this study, the effect of reinforced concrete columns on seismic loading was investigated. Full-scale columns were tested under slowly applied lateral load reversals. Both unidirectional and bidirectional loadings were included. The dimensions of the samples are 350x 
350x1000 mm. The axial load we used in our study is $600 \mathrm{kN}$. [8]

\section{Tanaka No. 5 Column}

(Tanaka,1990) Basically, in his thesis, he studied the effect of lateral limiting reinforcement on the ductile behavior of reinforced concrete columns. The dimensions of the samples are 550x $550 \times 1650 \mathrm{~mm}$. The axial load we used in our study is $968 \mathrm{kN}$. [9]

Table 1: Material and sectional properties of the selected columns

\begin{tabular}{|l|c|c|c|c|c|c|c|}
\hline \multicolumn{1}{|c|}{ Specimen } & Type & $\begin{array}{c}\text { Concrete } \\
\text { Strength } \\
\text { (MPa) }\end{array}$ & $\begin{array}{c}\text { Transverse } \\
\text { Steel - } \\
\text { Yield } \\
\text { Stress } \\
\text { (MPa) }\end{array}$ & $\begin{array}{c}\text { Transverse } \\
\text { Steel - } \\
\text { Strength } \\
\text { (MPa) }\end{array}$ & $\begin{array}{c}\text { Longitudinal } \\
\text { Steel - } \\
\text { Yield Stress } \\
\text { (MPa) }\end{array}$ & $\begin{array}{c}\text { Longitudinal } \\
\text { Steel Bar } \\
\text { Ratio \% }\end{array}$ & $\begin{array}{c}\text { Axial } \\
\text { Load } \\
\text { (kN) }\end{array}$ \\
\hline Bayrak_AS-6HT & Rectangular & 101.9 & 463 & 648 & 454 & 0.0258 & 4360 \\
\hline $\begin{array}{l}\text { Matamoros_C10- } \\
\text { 05S }\end{array}$ & Rectangular & 69.6 & 406.8 & 639.5 & 586.1 & 0.0193 & 142 \\
\hline Ohno_L2 & Rectangular & 24.8 & 325 & 0 & 362 & 0.0142 & 127 \\
\hline Saatcioglu_BG8 & Rectangular & 34 & 580 & 720 & 455.6 & 0.0293 & 961 \\
\hline Saatcioglu_U7 & Rectangular & 39 & 425 & 0 & 437 & 0.0321 & 600 \\
\hline Tanaka No.5 & Rectangular & 32 & 325 & 429 & 511 & 0.0125 & 968 \\
\hline
\end{tabular}

\section{Modeling on OpenSees}

The given material properties by the experimental results for each column are used in the numerical models. The concrete elements are modeled using Concrete04 for confined concrete and Concrete 01 for unconfined concrete, representing the concrete cover. Figure 3 displays the stressstrain relation for the concrete material. Reinforcing steel is utilized from the software library for the longitudinal reinforcing bar. The buckling of reinforcing bars is considered, and the unsupported length for local buckling is computed for each column (S). Calabrese et al. emphasized the numerical issues on the distributed plasticity and enlightened physical regularization techniques to eliminate them for the objective and non-objective responses [3]. Those physical regularization techniques are employed on the numerical models. For FB elements, the number of IP is selected using an aspect in which the plastic hinge length over the height of the column provides a good approximation. And for DB elements, the same perspective is implied to the height of the first element (employed two elements for all cases with 2 IP in each case). 


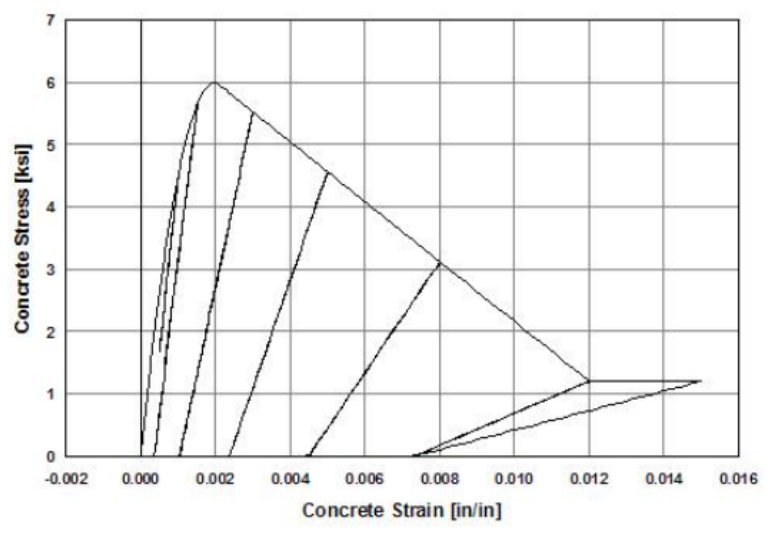

(a). Concrete01Stress - Strain Curve

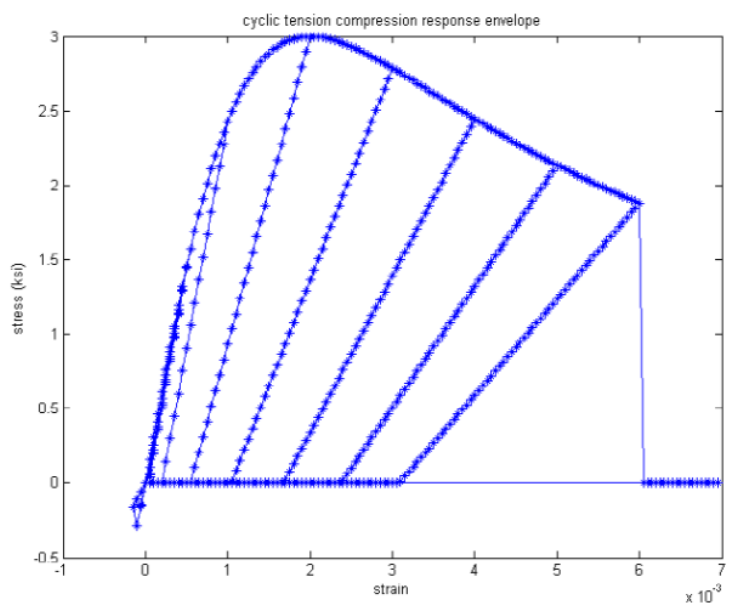

(b). Concrete04 Stress - Strain Curve

Figure 3: The selected models for confined and unconfined concrete in the models [10]

\section{Results}

Figure 4 compares the results obtained for each selected column using different fiber element types. In general, both element types provide good agreement with the experimental results. The displacement-based element provides a stiffer response, and the convergence problem can be observed, especially among the models with a high axial load level. The force-based element may have some difficulties regarding the convergence problem, and the divergence may occur at an early stage of the analysis; however, there is a greater agreement in terms of the maximum base shear between the experimental results. Pinching phenomena were able to capture through the numerical models in both element types because buckling is considered using reinforcing steel element for steel, and local buckling length is computed. The hardening and softening behavior of the columns (which is related to the axial load level) can be simulated well. The Bayrak AS-6HT column shows great agreements in both element types, while the FB elements show greater match specifically along with the softening range. The Matamoros column with the FB element is able to simulate the maximum and elastic zone better. Meanwhile, the model with the DB element shows some dispersions through the softening zone. The pinching behavior is captured better on the model with the FB element. The Ohno column model with the FB element displays a very good agreement on the softening range and is able to capture the ultimate displacement. Both models of the Saatcioglu BG8 column are not able to capture the pinching, but overall, they do have good agreement with the two models. The models for the Saatcioglu U7 column captures pinching very well. However, the model with the FB element shows lower and the model with the DB element higher global response than the experimental results. For the Tanaka column, the model with the FB element illustrates a better agreement regarding maximum response, softening zone, and pinching. The results are compared in detail in Table 2. 


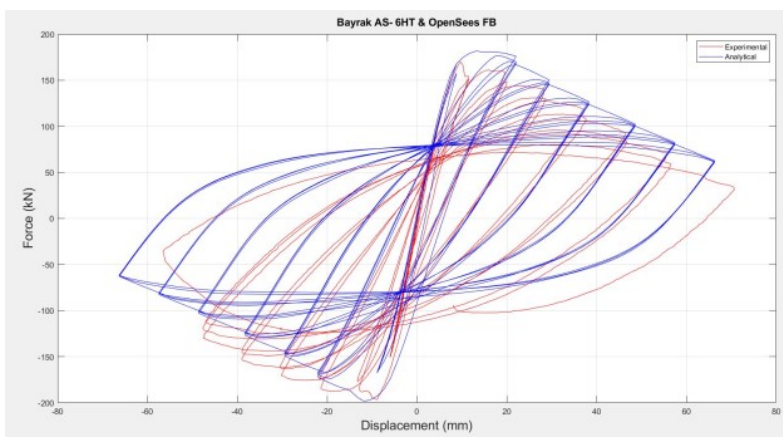

a. Bayrak AS-6HT FB

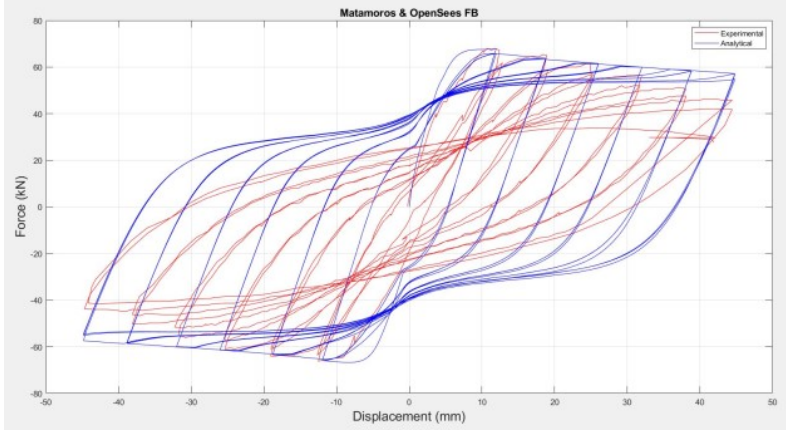

c. Matamoros FB

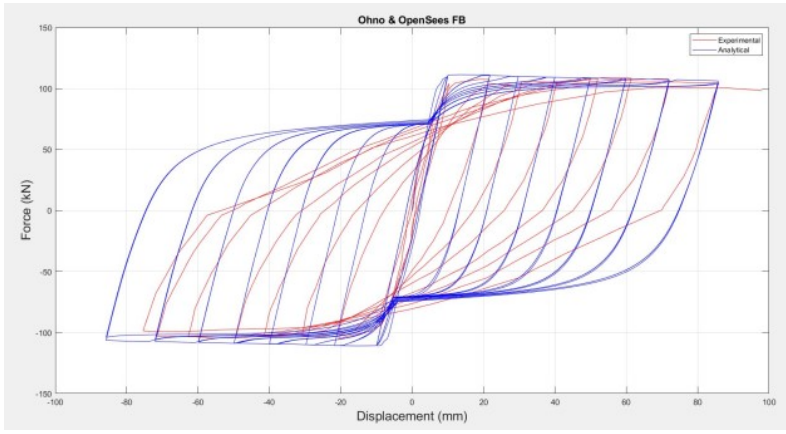

e. Ohno FB

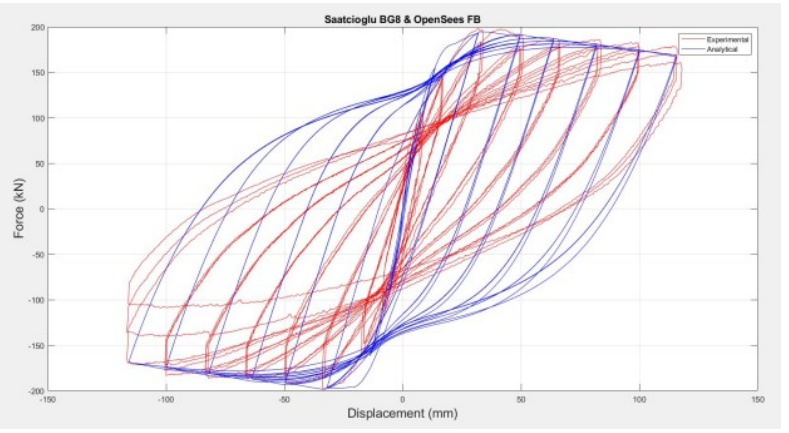

g. Saatcioglu BG8 FB

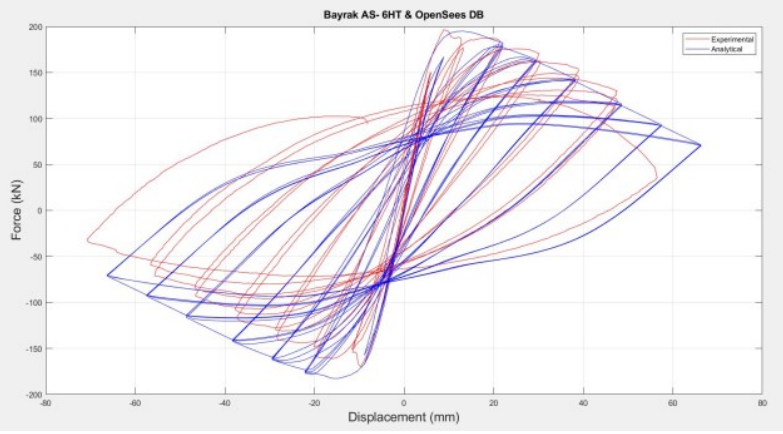

b. Bayrak AS-6HT DB

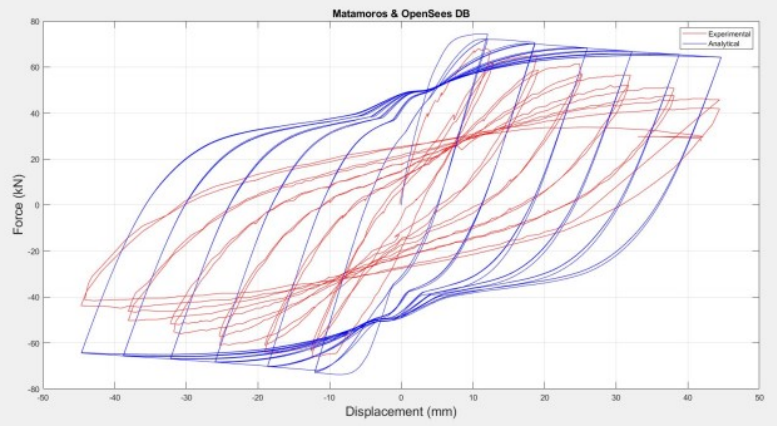

d. Matamoros DB

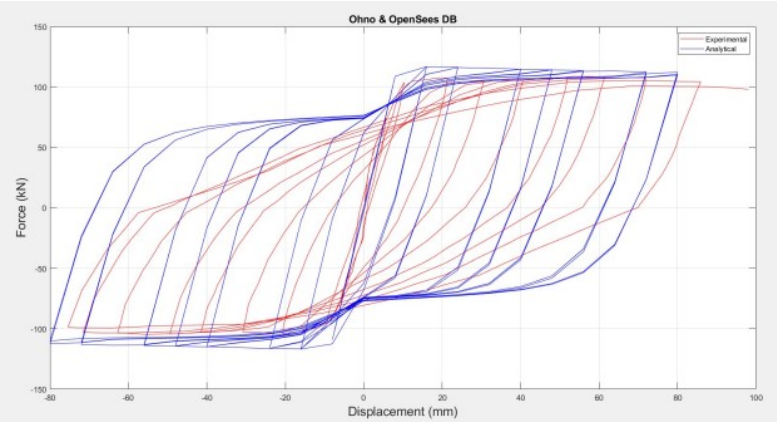

f. Ohno DB

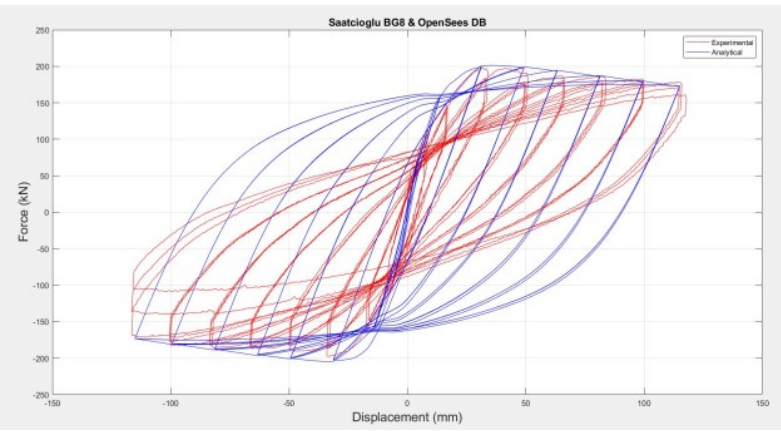

h. Saatcioglu BG8 DB 


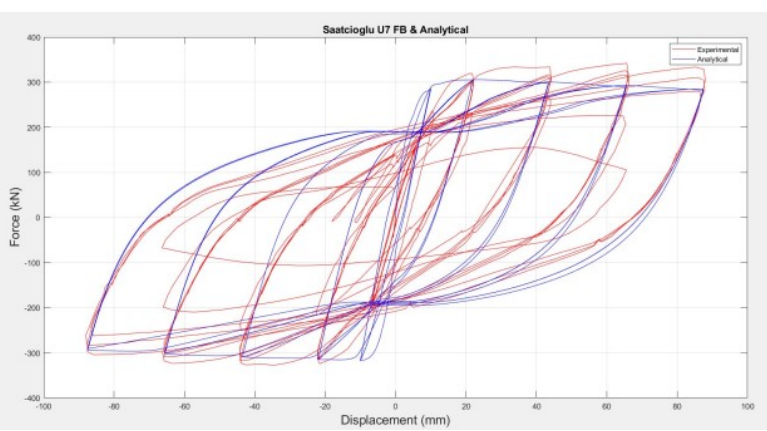

i. Saatcioglu U7 FB

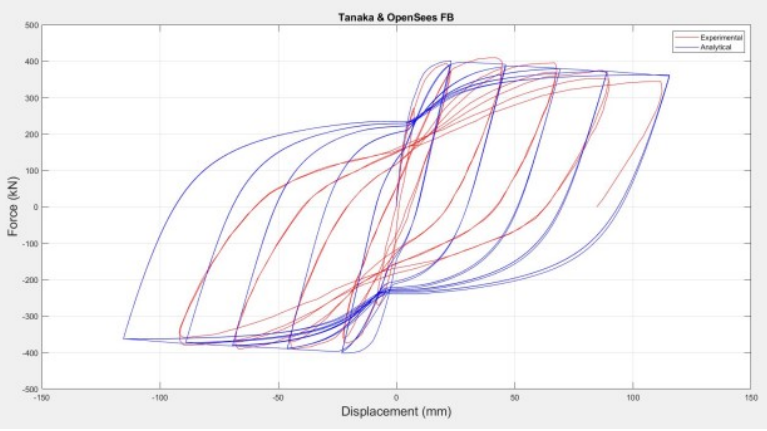

k. Tanaka FB

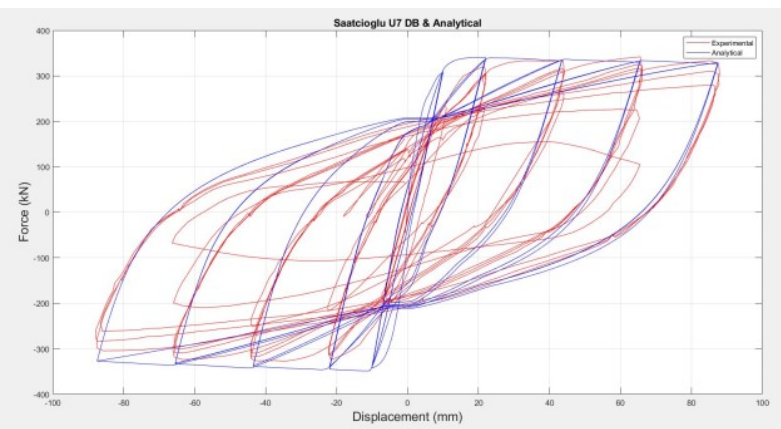

j. Saatcioglu U7 DB

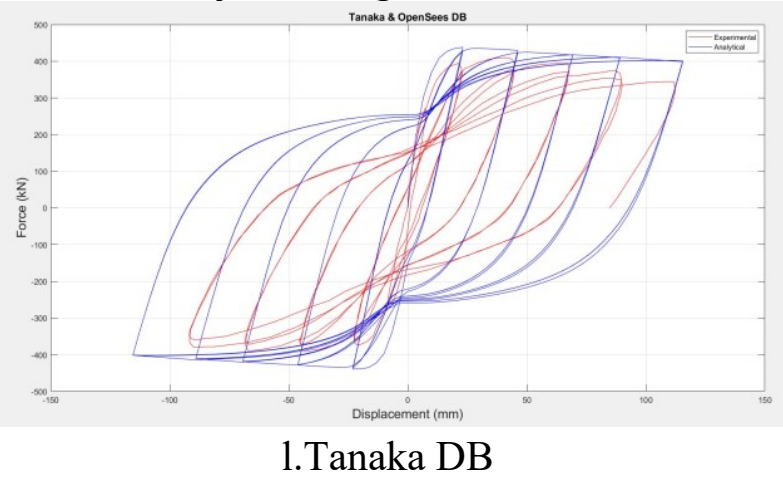

Figure 4: Comparison of the global responses for each column using FB and DB elements

\section{Summary and Conclusion}

This paper simulates six columns that are available in the literature using numerical models via the OpenSees software and figuring out the parameters that influence the global responses of the columns. Two types of the element, FB and DB elements, are utilized, and physical regularization techniques are employed while selecting IP numbers and the number of elements. In the global sense, very good agreements are achieved using both element types. However, the DB elements provided stiffer responses before the maximum point. The FB element, however, showed slightly better agreement in this paper. The physical regularization techniques are quite effective in reaching out the global match between experimental and numerical results considering the limited number of IPs and elements are employed in the models. 
(C)2021 Published in $5^{\text {th }}$ International Symposium on Natural Hazards and Disaster Management

Sakarya Uygulamalı Bilimler Üniversitesi Sakarya TURKEY 5-7 NOV 2021

DOI: doi.org/10.33793/acperpro.04.02.52

Table 2: Comparison of Experimental and Analytical Results

\begin{tabular}{|c|c|c|c|c|c|c|c|c|c|c|}
\hline \multirow[b]{2}{*}{ Specimen } & \multicolumn{6}{|c|}{ Experimental Tests } & \multicolumn{2}{|c|}{ Results using FB Elements } & \multicolumn{2}{|c|}{$\begin{array}{c}\text { Results using DB } \\
\text { Elements }\end{array}$} \\
\hline & $\begin{array}{l}\text { Width } \\
\text { (mm) }\end{array}$ & $\begin{array}{l}\text { Depth } \\
(\mathrm{mm})\end{array}$ & $\begin{array}{l}\text { Length } \\
\text { (mm) }\end{array}$ & $\begin{array}{c}\text { Axial } \\
\text { Load } \\
(\mathbf{k N})\end{array}$ & $\begin{array}{c}\text { S Hoop } \\
\text { Spacing } \\
\text { (mm) }\end{array}$ & $\begin{array}{c}\text { Maximum } \\
\text { Base Shear } \\
(\mathrm{kN})\end{array}$ & $\begin{array}{c}\text { Number of } \\
\text { Integration } \\
\text { Points FB }\end{array}$ & $\begin{array}{c}\text { Maximum } \\
\text { Base Shear } \\
(\mathrm{kN})\end{array}$ & $\begin{array}{c}\text { Length of } \\
\text { the first } \\
\text { element } \\
\text { (mm) }\end{array}$ & $\begin{array}{c}\text { Maximum } \\
\text { Base Shear } \\
(\mathbf{k N})\end{array}$ \\
\hline Bayrak_AS-6HT & 305 & 305 & 1842 & 4360 & 76 & 196.55 & 6 & 198.49 & 305 & 194.952 \\
\hline $\begin{array}{c}\text { Matamoros_C10- } \\
\text { 05S }\end{array}$ & 203 & 203 & 610 & 142 & 76.2 & 68.05 & 3 & 67.84 & 203 & -74.331 \\
\hline Ohno_L2 & 400 & 400 & 1600 & 127 & 100 & 108.70 & 4 & 111.35 & 400 & 116.787 \\
\hline Saatcioglu_BG8 & 350 & 350 & 1645 & 961 & 76 & 198.48 & 5 & 198.28 & 350 & 205.009 \\
\hline Saatcioglu_U7 & 350 & 350 & 1000 & 600 & 65 & 341.80 & 3 & 317.89 & 350 & 348.672 \\
\hline $\begin{array}{c}\text { Tanaka and Park } \\
\text { No.5 }\end{array}$ & 550 & 550 & 1650 & 968 & 110 & 409.20 & 2 & 401.58 & 550 & 438.962 \\
\hline
\end{tabular}

\footnotetext{
${ }^{*}$ Corresponding author: Fazil Abdulkadir Caglar Address: Faculty of Engineering, Department of Civil Engineering Sakarya University, 54187, Sakarya
} TURKEY.E-mail address: fazilabdulkadir.caglar@ibu.edu.tr 


\section{References}

[1] Andrei M. Reinhorn, Michael R. Willford, Gregory G. Deierlein, «Nonlinear Structural Analysis For Seismic Design,» National Institute of Standards and Technology, 2010.

[2] «PEER Structural Performance Database,» 2003. [Çevrimiçi]. Available: https://nisee.berkeley.edu/spd/index.html.

[3] Joao Pacheco Almeida, Rui Pinho, Armando Calabrese, «Numerical Issues in Distributed Inelasticity Modeling of RC Frame Elements for Seismic Analysis,» Journal of Earthquake Engineering , 2010.

[4] Oguzhan Bayrak and Shamim A. Sheikh, «Confinement Steel Requirements For High Strength Concrete Columns,» Elsevier Science, 1996.

[5] Adolfo Benjamin Matamoros, Study of Drift Limits For High-Strength Concrete Columns, 1994.

[6] Tomonori Ohno and Takashi Nishioka, «An Experimental Study on Energy Absorption Capacity of Columns in Reinforced Concrete Structures,» Structural Engineering, October 1984.

[7] Murat Saatcioglu and Mongi Grira, «Confinement of Reinforced Concrete Columns With Welded Reinforcement Grids,» ACI Structural Journal, February 1999.

[8] Murat Saatcioglu and Guney Ozcebe, «Response of Reinforced Concrete Columns to Simulated Seismic Loading,» ACI Structural Journal, February 1989.

[9] Jin Tanaka, Effect of Lateral Confining Reinforcement on the Ductile Behavior of Reinforcement Concrete Columns, 1990.

[10] «The Open System for Earthquake Engineering Simulation,» 2006. [Çevrimiçi]. Available: https://opensees.berkeley.edu/.

\footnotetext{
* Corresponding author: Fazil Abdulkadir Caglar Address: Faculty of Engineering, Department of Civil Engineering Sakarya University, 54187, Sakarya TURKEY. E-mail address: fazilabdulkadir.caglar@ibu.edu.tr
} 